\title{
Effects of COVID-19 Pandemic on Mental Health of Youths in Nigeria: The Counselors Intervention Strategy
}

\author{
Godwin Michael Ubi ${ }^{{ }^{*}}$, Bassey Ekeng Effiom ${ }^{2}$ and Stella Esuabana ${ }^{2}$ \\ ${ }^{1}$ Department of Genetics and Biotechnology, Faculty of Biological Sciences, University of Calabar, \\ P.M.B 1115, Calabar, Nigeria. \\ ${ }^{2}$ Department of Guidance and Counseling, Faculty of Education, University of Calabar, P.M.B 1115, \\ Calabar, Nigeria.
}

Authors' contributions

This work was carried out in collaboration among all authors. Authors BEE and GMU designed the study, authors SE and BEE performed the statistical analysis, authors GMU and SE wrote the protocol, authors SE and BEE wrote the first draft of the manuscript. Authors GMU and BEE managed the analyses of the study. 'Author SE' managed the literature searches. All authors read and approved the final manuscript.

Article Information

DOI: $10.9734 / A R R B / 2021 / \mathrm{v} 36 i 530375$ Editor(s):

(1) Dr. David E. Martin, DFH Pharma Inc, Gaithersburg. (2) Dr. Md. Torequl Islam, Federal University of Piaui, Brazil.

(3) Paola Angelini , University of Perugia, Italy. Reviewers:

(1) Diego Mendonça Viana, Faculdade Princesa do Oeste (FPO), Brazil. (2) Raquel Rangel Cesario, Centro Universitário Municipal de Franca, Brazil. (3) Igor Luiz Vieira de Lima Santos, Federal University of Campina Grande, Brazil. Complete Peer review History: http://www.sdiarticle4.com/review-history/64473

Original Research Article

Received 21 December 2020

Accepted 30 January 2021 Published 03 June 2021

\begin{abstract}
In late December, 2019, patients diagnosed with viral pneumonia due to an unidentified microbial agent were reported in Wuhan, China. A novel coronavirus was subsequently identified as the causative pathogen, provisionally named 2019 novel coronavirus (2019-nCoV). As at November 10, 2020 , confirmed cases had reached an alarming 50,994,215 with a global death toll of 1,264,077 from 2019-nCoV infections, most of which involved people living in or visiting countries with high rate of prevalence and thus increasing the human-to-human transmission. A random sampling of 150 inmates in a Psychiatric clinic revealed that the advent of the COVID 19 pandemic in Nigeria left many youths stressed up, depressed, traumatized with excited state of anxiety leading to mental
\end{abstract}


health challenges and some of which resort to committing suicide. The post COVID 19 era plunged many youths into joblessness. Many youths who were into artisans and gainfully employed with private outfits and organizations such as private schools lost their jobs $(20.67 \%)$ due to the COVID 19 disease outbreak which shut down schools, businesses and government. The state of joblessness of the youths in the current post COVID 19 era has further affected the mental health of some of the youths in Nigeria. Absence of government palliatives (4.00\%), ASUU Strike (3.33\%), High level of poverty, isolation, Sicknesses (13.33\%), High level of Despondency, Loss of accommodation (16.67\%), Inflation (increased prices of food and other items), Increased transportation cost, Persistent lockdown, Social unrest, High level of insecurity (17.33\%), Security personnel brutality and Increase crime rates. The counselor's intervention strategy should focus on helping the youths with poor mental health due to COVID 19 to regain self- confidence, regain self esteem, seek medical attention for them, canvass for free medication for affected ones, create awareness on job opportunity for them, engage governments on behalf of the youths for employment opportunities as well as giving them palliatives, reopening of schools/universities and linking them to credit facilities, social safety nets and other available opportunities.

Keywords: Mental health; COVID 19 era; youths; counseling strategies; interventions.

\section{INTRODUCTION}

In 2019, patients diagnosed with viral pneumonia due to an unidentified microbial agent were reported in Wuhan, China [1]. A novel coronavirus was subsequently identified as the causative pathogen, provisionally named 2019 novel coronavirus (2019-nCoV). As at November 10, 2020, confirmed cases had reached an alarming $50,994,215$ with a global death toll of $1,264,077$ from 2019-nCoV infections, most of which involved people living in or visiting countries with high rate of prevalence and thus increasing the human-to-human transmission [2].

In addition, 2019-nCoV has now been reported in almost 195 countries of the world including Italy, Malaysia, Belgium, Australia, Nigeria, Portugal, Germany, USA, France, Brazil, Egypt, South Africa, Canada, USA, UK, Russia, Israel, Turkey, Iran, Vietnam, China and Spain [3]. Infections of medical workers and family clusters have also been reported and human-to-human transmission confirmed in most of these countries. Most of the infected patients had a high fever, dry cough, tiredness, chills, chest pain, shortness of breath, loss of taste and smell and dyspnea, with chest radiographs revealing invasive lesions in both lungs which affects the healthy living of infected persons [4].

The devastating effect of the COVID 19 on humanity has reached an alarming proportions ruining families, businesses and shorting down governments for the first time in this century. The resulting death toll has left many young people as orphans, jobless, sick, traumatized, stressed and downtrodden. These probably may not be left unconnected with the recent \#endsars\# (sars is special anti-robbery squad) in Nigeria protest which escalated into arson, looting and mayhem by mostly youths in Nigeria on the government, prominent individuals and corporate organizations assets [5].

Having a healthy mind and spirit is just as important as having a healthy body. When your mind and spirit are healthy, you have the emotional strength to take care of yourself and your family, to see problems and do your best to solve them, to plan for your future, and to form satisfying relationships with others. When you are mentally healthy, you can accept help from other people and still value yourself [6].

Many people develop mental health problems that make it hard for them to face challenges, feel satisfied with their lives, or contribute meaningfully to the society. Sometimes, these mental health problems are caused by prevailing circumstances such as the COVID 19 pandemic. But usually, they are propelled by a number of indicators which are an aftermath of the crises [7].

This paper tries to describe the challenges to mental health that many youth faces. It also describes common mental health problems and gives counseling suggestions and strategies on how to work toward feeling better. It also shows how individuals, families, the society and government can promote mental health of the youths especially in this trying times where the COVID 19 pandemic is at the verge of taking a second wave across the globe. 


\subsection{Some Causes and Signs of Poor Mental Health in Youths}

Youths with poor mental health are at risk and are more prone to mental illness if they have had mental health problems in the past if they have lost family members, are sick, stigmatized or are separated from their families, witnessed violence or have violent partners or have little or no social support to make living meaningful for them [8].

A person with unpleasant and unusual questionable attitude may be mentally ill if he/she has any of these signs:

i. They hear voices or sees unusual things that others do not hear or see (hallucinations).

ii. They have strange beliefs that interfere with daily life (delusions) for example, they think their neighbors are trying to harm them.

iii. They no longer cares for themselves for example, they do not get properly dressed, clean or eat good food

iv. They behave in a strange way, like saying things that make no sense.

Similar signs can be caused by some diseases, poisoning, medicines, drug abuse, or damage to the brain. People who are not mentally ill sometimes act in ways that make others question their mental health, particularly if these behaviors are related to beliefs or traditions that are not shared by the society. For example, if a person says they received guidance in a "vision," they may be drawing upon traditional sources of knowledge and guidance and not suffering from hallucinations or mental illness. These signs are more likely to be signs of mental illness if they come so often and are so strong that a person has difficulty carrying out daily activities [9].

\subsection{Some Challenges Posed by Post COVID 19 Pandemicon Youths}

Stress, discrimination, isolation, and traumatic events are some of the challenges to mental health that so many youths or young people are faced with. Of course, not everyone especially the youths are able to cope with the problems facing the current times, thus leading to severe social unrest in the society and developing mental health problems for some individuals who cannot cope [10]. Stress, for example, is not a mental health problem, although when you can no longer cope with the challenges you face, too much stress has become a problem. Traumatic events in your life do not always cause mental health problems, but if you have no support in trying to understand them and work through them emotionally, they often do. When thinking about mental health problems, remember: There is no clear line between normal responses to life's events and mental health problems [11].

Most people have some of the signs orchestrating or inducing mental health challenges at different times in their lives [12], because everyone faces problems at one time or another. Signs of mental health problems can vary from individual to individual and from community to community. Behavior that looks strange to an outsider may be a normal part of a community's traditions or values. Some of the challenges posed by the first wave of COVID 19 era on youths include stress, physical changes, diseases, poverty, isolation, lost of job skills and anxiety $[4,13]$

\subsubsection{Stress}

When young people are faced with a lot of stress every day and for a long time, they begin to feel overwhelmed and unable to cope. The problemmay be made worse if they have been taught not to value themselvesand to neglect their own needs which is practically impossible at this time. The COVID 19 era has produced long periods of starvation, deprivation, loss of jobs, sickness, ejections from homes, widespread poverty among the youths, sicknesses, kidnapping, raping, burglary, banditry, armed bandits, robbery, and many more societal ills capable of inducing fear and stress on youths $[9,14]$.

\subsubsection{Physical changes and disease caused by stress on the youths}

When the youths experience stress, their body gets ready to react quicklyand fight off the stress. Some of the changes that occur will includethe heart starts beating faster,the blood pressure increasing and an increasing pulse or breathes rate with a resultant reduction in the rate ofdigestion, thus steering up cardiovascular disorder [15] .

If the stress is sudden and severe, they may feel these changes in their body. Then,once the stress is gone, their bodies returns to normal. But 
if the stress is less severeor happens slowly, they may not notice how the stress is affecting their body, eventhough the signs are still there.Stress that goes on for a long time can lead to the physical signs common inanxiety and depression, such as headache, intestinal problems, and lack of energy.Over time, stress can also cause illness, such as high blood pressure, hypertension and cardiac failure [16].

\subsubsection{Social barriers create stress}

Many of the same barriers that prevent people especially youths from getting healthcare also cause stress in their daily lives. Since they face so many sources of stress, itis especially important for the youths under any form of stress to find the support they need tofeel strong and confident in their abilities and to maintain theirself-esteem [17].

\subsubsection{Poverty in Nigeria}

When a family is extremely poor (below 1 dollar a day), it is harder for a person (child) to get the skills they needsto work. They may not get the required tools or money they need in order to go to school. If such youths in such condition does not have a chance to help or support the family, they maytreat them as a burden. If the family has only a little food, they may decide more food should go to the family members who go out to work and help support them [18]. Most of the country's population lives below the poverty line and the young people faces severe hardship even before the onset of COVID 19 pandemic.

\subsubsection{Isolation}

Youths may grow up separate from other children due to COVID 19 infections and not have the chanceto develop friendships. They may not learn the social skills they need to buildstrong relationships as adults. Being alone and in prolonged isolation maycreates stress. Having friendsand being part of a society is critical and important for good self-esteem [19].

\subsubsection{Lost of job skills}

The post COVID 19 era have made youths who are acquiring job skills to be less likely to receivetraining for work so they can earn money. If they havenot had a chance to gain job skills due to COVID 19, it will be harder forthem to support their families and themselves [20].

\section{METHODOLOGY}

A random sampling of 150 inmates of the Psychiatric hospital Calabar was taken to ascertain the indices and vivid cause of the mental challenge confronting them. This was done in the months of August and September 2020. The instrument for data collection was a simple questionnaire and oral interview of the care givers with them. The bio-data was deliberately skipped for confidentiality purposes and to elicit quick response from the inmates. The results obtained are presented in Table 1 below as follows

\section{RESULTS}

\subsection{Causes of Youths Mental Health Challenges Inpost COVID-19 Era in Nigeria}

\subsubsection{Loss of jobs}

The post COVID 19 era has plunged many youths into joblessness. Many youths who were into artisans and gainfully employed with private outfits and organizations such as private schools lost their jobs due to the COVID 19 disease outbreak which shut down schools, businesses and government. The state of joblessness of the youths in the current post COVID 19 era has further affected the mental health of some of the youths in Nigeria.

\subsubsection{Absence of government palliatives}

In Nigeria, the government palliatives that was released for the citizenry during the heat of lockdown for COVID 19 did not get across to a high proportion of the youths across the country. This contributed immensely to the stress suffered by youths during and after the COVID 19 era. Absence of any form of palliative to cushion the effect of lockdown on youths in terms of money, foodstuff and drugs induced untold hardship on the youths, which consequently affected their mental health.

\subsubsection{ASUU strike and school shut down}

The prolonged and lingering strike of the academic staff union of Universities (ASUU) has unarguably induced a serious challenge to the mental well-being of the youths in Nigeria. Most of the youths who were due to graduate in same year are despondent as the strike lingered. The 
student goals and motives has been affected and altered due to the strike. Many youths have seize the opportunity of idleness at home to indulge in activities that are inimical to the society such as robbery, gangsterism, smoking of weeds and bitch drinking, gambling and all the social vices one can think off, thereby becoming susceptible to poor mental health development.

\subsubsection{High level of poverty}

With the high wave of job losses and absence of palliatives from government to a majority of the youths, there is widespread poverty in the land especially among the youths who deserves better feeding and balance diet for their proper development. Not eating what they need to eat and leaving below 1 dollar a day for a family in Nigeria has inflicted so much pains and poverty in the land. A hungry youth is an angry youth they say. Hunger due to poverty induces several health challenges including stomach ulcer, headache, backache, poor mental health, overreaction, stress, trauma and anxiety.

\subsubsection{Isolation}

The COVID 19 era saw several thousand of youths in Nigeria and beyond going into self isolation due to social distancing rule and human-to-human contact infection. Self- isolation of the youths and the fears associated with the belief that the COVID 19 infection was already a death sentence, most of the infected youths developed poor mental health resulting from the trauma and experience of COVID 19. The COVID 19 era also brings the awareness of the unimaginable coming of the second wave of the COVID 19 pandemic with a much higher greater impact on society, individuals, families, schools, businesses and governments. This has generated much fear in the youths with resultant mental health deterioration for some especially those who has a stench with any of the COVID 19 associated illnesses.

\subsubsection{Sicknesses}

Poor dieting, widespread poverty among the youths and absence of street cleaners during the COVID 19 lockdown in Nigeria has ushered in a dirty environment under which most the communicable and non- communicable disease causing pathogens come to thrive in the present post COVID 19 era. Malaria parasites and vectors such female anopheles mosquitoes transmitting Plasmodium falciparium through bites, Salmonella typhii, Vibrio cholera amongst others are prevalent due to filthy environment occasioned by the prolong COVID 19 lockdown. Youths on medication could not go out for their medication and lots more. These induce serious mental health challenges among the youths in the post COVID 19 era.

\subsubsection{High level of despondency}

The loss of hope for anything good offers a serious threat to good mental health among the youths. Most of the youths have lost their jobs, no school activities, no money in their pockets, no fun, no hangouts, no picnic and increase in self-pity is the prevailing circumstance of most youths at the moment. This scenario leads to poor mental health challenge for the youths and the society at large.

\subsubsection{Loss of accommodation}

The widespread poverty in the land, the loss of sources of livelihood by many youths rendered many homeless due to their inability to renew their rents. Many youths have relocated to the rural areas with despondency. Some have been ejected from their houses and workshops as a result of their inability to pay rents. This can cause mental challenge to the youths that are directly affected.

\subsubsection{Inflation (increased prices of food and other items)}

The current prevailing market prices for all goods and services has increased tremendously by more than 4 fold. Most youths who are out of school, jobless cannot purchase anything the need. This has plunge some of the youths into nefarious acts in other to buy their needs. Those who cannot indulge in any unlawful acts to meet their demand will definitely feel rejected, self-pity and traumatized leading to poor mental health development.

\subsubsection{Increased transportation cost}

The post COVID 19 era have witnessed an unprecedented increase in the cost of rural - to urban transportation and within urban transportation have made so many of the youths to go about on foot walking on pedestrian pathways looking for jobs and means of livelihood. The widespread poverty in the land and high cost of intra and inter- city movement occasioned by the lockdown and curfews have 
consistently restrained youths from going about their legitimate businesses thereby confining them to their abode is enough to induced mental health challenges on the youths.

\subsubsection{Persistent lockdown}

The persistent lockdown in most states in Nigeria due to the COVID 19 pandemic as witness recently kept so many youths indoors continuously and caused their idle minds and hands to jitter. Youths in persistent lockdown conditions are rather imprisoned and caged. This slows down their emotions and induced stress and anxiety in them which can lead to their mental health deterioration.

\subsubsection{Social unrest}

The uprising of social unrest in Nigeria as evident in the recent \#endsarsprotest\# leaves a devastating blow and injury to the minds of many youths who feel insecure and threatened by the hard and tough times in the land. The post COVID 19 era has witness high volume of social unrest from the youth wings ranging from one protest to the other, leading to arson, looting and death of many youths. This has also many youths to be traumatized. This posts a great threat to the mental health development of the youths.

\subsubsection{High level of insecurity}

The aftermath of the \#endsarsprotest\# in Nigeria saw the withdrawal of security personnel from their duty posts arising from their threats and damages they suffered during the youth protest. This left the lives and properties of everyone at the mercy of hoodlums and vagabonds who now took advantage of the withdrawal of security personnel from the streets to unleash mayhem to unsuspecting members of the public. This scenario has created a high level of panic and insecurity amongst the gullible youths who are prone to mental health challenges.

\subsubsection{Security personnel brutality}

The COVID 19 era witnessed the protest against security personnel brutality in Nigeria. This was the straw that broke the Carmel's back. Security personnel brutality was seen as the major threat to the youths from the stand point of SARS and the protest. Some youths have been brutalized by security personnel. These youths who have experienced the security personnel brutality live in fear and trauma. This also affects their mental health and wellbeing.

\subsubsection{Increase crime rates}

There has been increased in crime rates ranging from increased rate of kidnapping, increased robbery incidence, increased cases of rape and domestic violence after the \#endsarsprotest\# in Nigeria.

\subsection{Counseling Strategies for Youths with Metal Health Challenges Occasioned by COVID 19 Realities}

Based on the findings of this research, the counselor's intervention strategy should focus on;

i. Helping the youths with poor mental health due to COVID 19 to regain selfconfidence,

ii. Regain self -esteem, seek medical attention for them,

iii. Canvass for free medication for affected youths,

iv. Creating awareness on job opportunity for the youths,

v. Engaging governments on behalf of the youths for employment opportunities for the youths,

vi. Sourcing for and giving palliatives to the youths,

vii. Engaging government to reopen tertiary institutions

viii. Linking youths to credit facilities, social safety nets and opportunities.

\subsubsection{Getting help and care for mental illness}

Although in most places family members care for those who are mentally ill, it is best if the person can also be treated by a trained mental health worker. In some situations medicines are necessary, but they should never be the only treatment.

Traditional healers often play an important role in treating mental illness. A healer who comes from the same community as the person with the problem may know them and their families better, understand them, and have a clear idea of the stresses they have experienced. Some healers use treatments or rituals that can help a youth overcome the problem. No matter what treatment is given, a person with a mental illness should 
always be treated with kindness, respect, and dignity.

\subsubsection{Working toward mental health}

To build a better life, the youths need health, education, and the ability to move around independently and earn a living. But the difficulty in achieving these goals can create challenges to youths mental health. They usually do not need treatment from a trained mental health worker to overcome most feelings of depression, anxiety, or low self-esteem. There are ways they can help themselves and ways they can begin to feel better with the support of another person or a group [21].

\subsubsection{Strategy to help overcome reactions to trauma}

If a youth have suffered a trauma, theymay need help to learn to trust others again.

Talking about their life before the trauma as well as their current experiences. This way they can realize that although life has changed a lot, inmany ways they are the same person as before. Expressing painful things that are too difficult to talk about or that are 'buried' where they cannot be remembered. Exercises like drawing or painting, or a healing activity like massage, can help them expressly or relieve these painful feelings [22].

A traumatized youth to keep a valuable object of their new life nearby as they sleep. This way if they dream of the trauma and wake and see their valuable object will help them remember that they are now safe.

\subsubsection{If someone you know has experienced trauma}

At first it may be best for friends, families, or caregivers of a woman who has experienced a trauma to do everyday activities together with her or to do some of them for her if that is what she wants. You can let her know you are willing to listen and wait till she feels ready to talk. Later, when it seems right, encourage her to take up some of the same activities she enjoyed before or that were part of her daily routine [23].

Table 1. Indices of Post COVID-19 Effect on Youth Mental health and their consequences

\begin{tabular}{llll}
\hline & Post COVID 19 effects & No. of youths respondent & \% of Youth Affected \\
\hline 1 & Loss of Jobs & 31 & 20.67 \\
2 & Insecurity & 26 & 17.33 \\
3 & Loss of Accommodation & 25 & 16.67 \\
4 & Sickness & 20 & 13.33 \\
5 & Inflation & 8 & 5.33 \\
6 & Absence of palliatives & 6 & 4.00 \\
7 & Despondency & 6 & 4.00 \\
8 & Absence of social amenities & 6 & 4.00 \\
9 & Increased rape cases & 6 & 4.00 \\
10 & Increased robbery incidence & 5 & 3.33 \\
11 & Increased transport cost & 5 & 3.33 \\
12 & ASUU strike & 5 & 3.33 \\
13 & Increased rate of kidnapping & 4 & 2.67 \\
14 & Loss of loved ones/valuables & 3 & 2.00 \\
15 & Low farm outputs & 3 & 2.00 \\
16 & Persistent lockdown & 1 & 0.67 \\
\hline & Total & $\mathbf{1 5 0}$ & $\mathbf{1 0 0}$ \\
\hline
\end{tabular}




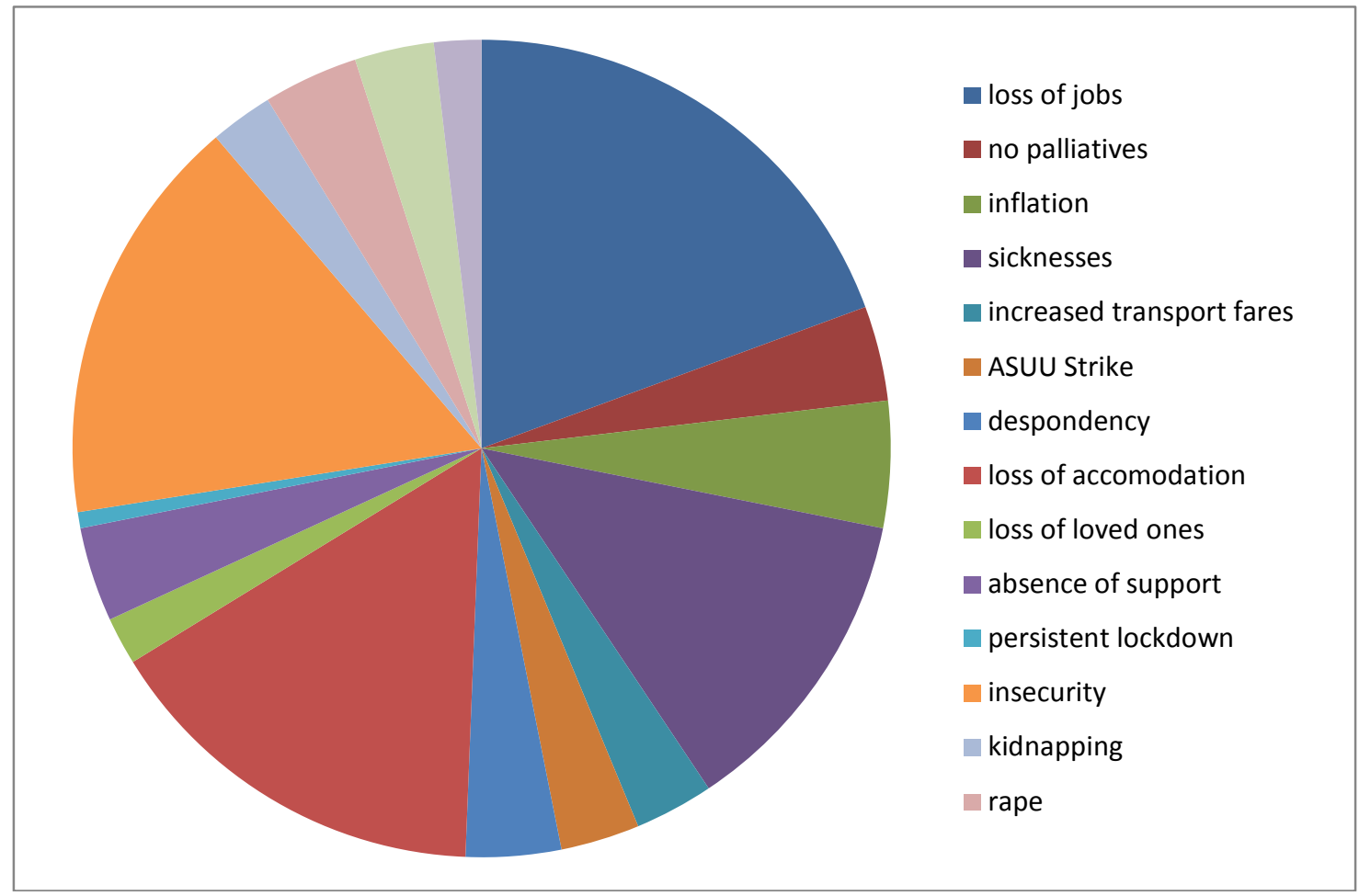

Fig. 1. Pie chart showing indicators of mental health challenges of youths due to COVID 19 pandemic in Nigeria

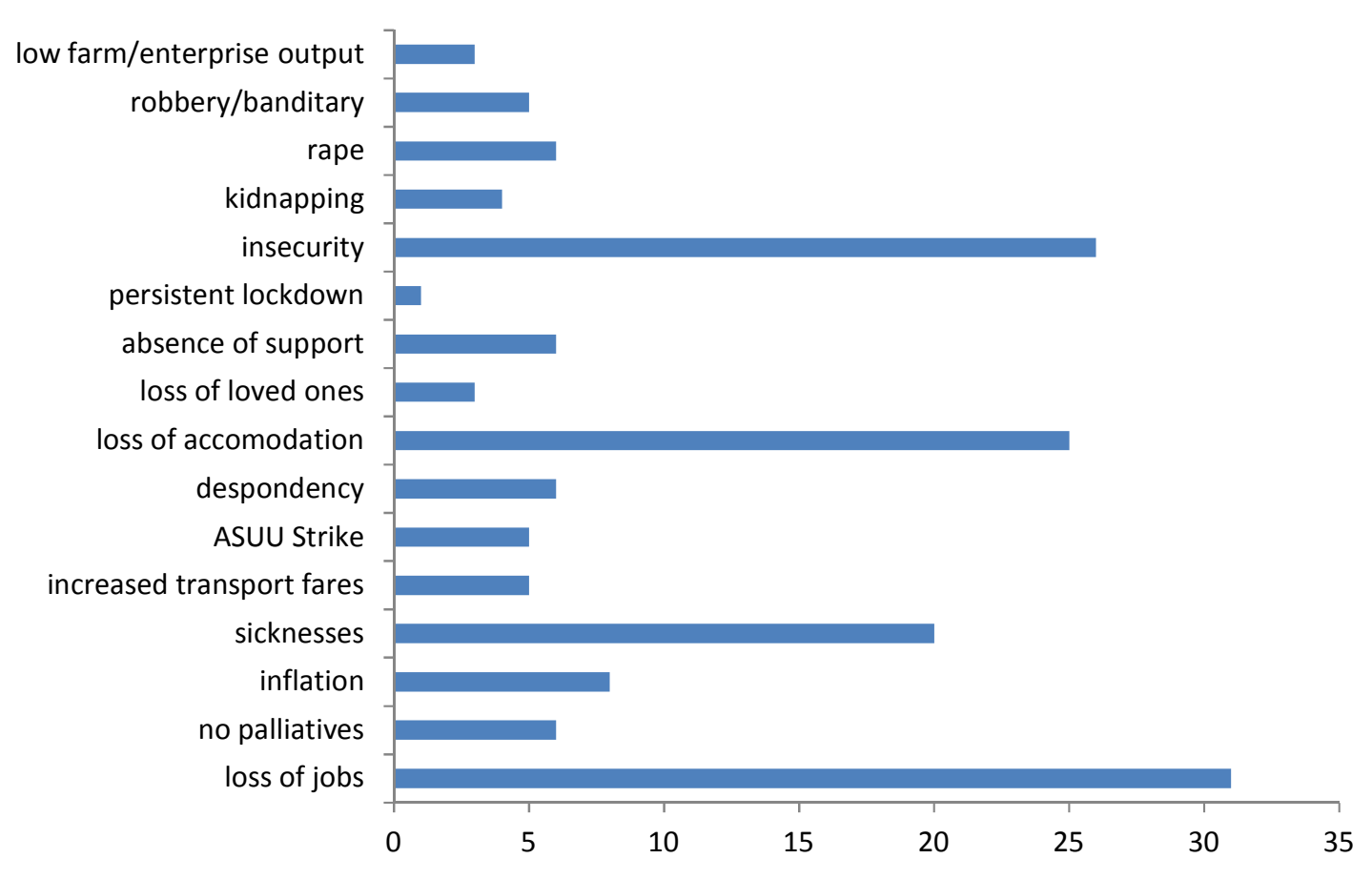

Fig. 2. Bar chart showing proportion of poor mental health indicators of youths in the post COVID 19 era in Nigeria 


\subsubsection{If you think someone has a mental health problem}

If you suspect a youth with a mental health problem, get to know them better as a counselor. Listen to what other people are saying about their behavior and the ways they has changed. Since mental health problems often have roots in the family or society, think about how these may contribute to the problem. But not all mental health problems have causes that can be identified. Sometimes we just do not know why someone develops a mental health problem.

\section{DISCUSSION}

\subsection{Depression Due to Loss of Loved Ones}

According to [24], depression affects almost 5 in 10 youths when compared with around 2 in 10 people. This is not surprising, because many youths do not have the chance to get educated, develop confidence, or learn how to do things for themselves. As they grow older, the social barriers and changes in their health that makes it more difficult to do as much as you used to, make them more likely to feel unhappy and depressed. This is noticeable from the present study. Depression occurs in the youths making them to feel sad most of the time, have difficulty in sleeping, too much thinking and clear loss of interest in pleasurable activities, eating, or exerts physical problems, such as headaches or intestinal problems, that are not caused by illness but lack of energy for daily activities leading to thinking about death or suicide.

\subsection{Suicide Attempt Due to Rape and Kidnapping}

Serious depression can lead to suicide (killing oneself). Some youths have thoughts of suicide at least once in their life. But when these thoughts come more and more often or get very strong, such youths need help from a trained counselor or mental health worker right away. Questions such as, are you feeling lonely and isolated from family or friends? Have you lost the desire to live? Do you regularly use alcohol or drugs? Do you have a serious health problem? Have you thought of killing yourself? Have you ever tried to kill yourself? Are often used to verify consent to suicide. If the answer to any of these questions is 'yes,' then such a youth is likely to commit suicide and thus need the help of the counselor. Some medical counselors or doctors also may use medicines to treat depression [25]. The findings from this study shows that the youths can also liable to the act of committing suicide if not counseled properly.

\subsection{Anxiety of Loss of Jobs and Despondency}

According to [26], if feelings of nervousness or worry (other common names for anxiety are 'nerves,' 'nervous attacks,' and 'heart distress') continue for a long time or become more severe, then you may have a mental health problem. The youths may show such signs as feeling tense and nervous without reason, sweating, feeling the heart pound (when there is no heart disease)frequent physical complaints that are not caused by physical illness and that increase when you are upset[27,28].

\subsection{Panic Attacks Due to Robbery/Banditry}

Panic attacks are a severe kind of anxiety. They happen suddenly and can last from several minutes to several hours. In addition to the signs above, you may feel terror or dread, and fear you may lose consciousness (faint) or die. You may also have chest pain, difficulty breathing, and feel that something terrible is about to happen [29].

\subsection{Trauma Due to Insecurity}

When something horrible has happened to a youth, they had suffered a trauma. Some of the most common kinds of trauma are violence in the home, rape, war, torture, and natural disasters. Trauma threatens a youth's physical or mental wellbeing, or both. As a result, theyfeel unsafe, insecure, helpless, and unable to trust the world or the people around them. It can take a long time for a youth to recover from trauma, especially if it was caused by another person [30,31].

\subsection{Mental Health Challenge Caused by Underlying IIInesses}

When a youth becomes disabled later in life, because of war, an accident, or an illness, the sudden change can be very difficult for them. Some youths who are newly disabled may feel they have lost all worth to themselves, their families, and communities [32,33]. They may also be afraid or disturbed because of a trauma that has happened to them. Often, a youth who 
becomes disabled later in life has grown up with confidence, good education, and many skills. They may have always had strong relationships with others and expects to be treated with respect. When theybecomes traumatized, it can take time to adjust to the changes in their body. It can be even harder to adapt to the changes in how other people see them, or how they sees themselves [34,35].

\subsection{Reactions Due to Trauma Occasioned by Fear and Difficult Situations, No Support, Inflations}

If you have experienced trauma, you may have many different reactions, such as: going over the trauma again and again in your mind. While you are awake, you may keep remembering the terrible things that happened. At night, you may dream about them or be unable to fall asleep because you are thinking about them [36].

1. Feeling numb or feelingemotions less stronglythan before. You may avoidpeople or places that remind you of the trauma [37].

2. Becoming very watchful. If you are constantly looking out for danger, you may have difficulty relaxing and sleeping. You may overreact when startled [38].

3. Feeling very angry or full of shame about what happened. Ifyou have survived a trauma where others died or were seriouslyinjured, you may feel guilty that others suffered more than you did $[39,40]$.

4. Feeling separate and distant from other people $[41,42]$.

5. Having outbursts of strange or violent behavior, in which you are confused about where you are $[43,44]$.

Many of these signs are normal responses to a difficult situation. For example, it is normal to feel angry that a trauma has happened, or to be watchful if the situation is still dangerous. But you need help if the signs are so severe that you cannot carry out daily activities, or if the signs start months after the trauma has happened $[45,46]$. These help can come from the counselor's strategies.

\section{CONCLUSION}

Counselors should prepare themselves for the greater tasks of mainstreaming all the categories of youths who have developed mental health challenge due to COVID 19 pandemic in Nigeria and other causes and be able to integrate them back into the functional society adopting any of the several aforementioned intervention strategies. As a first step, they must clarify their feelings and attitudes about working in a society where everybody is adjust as sub normal.

Attitudes such as Pity, low expectation, repulsion to physical abnormalities, misinformation, and other biases should be eliminated for effective counseling of mentally challenged youths. Correct information and direct experience can facilitate accurate awareness and acceptance of this category of persons into the society. In addition, counselors must obtain knowledge and training for working with youths with mental challenges. They can obtain this knowledge and training by working with institutions saddled with the responsibility of taking care of youths with exceptional needs throughthe organization of counseling workshops, consultation, supervision, current therapeutic literature, and the use of community resources. With these strategies, mentally challenged youths due to COVID 19 pandemic can be properly mainstream and reintegrated into the society.

\section{RECOMMENDATIONS FOR FUTURE PERSPECTIVES}

To effectively address youth restiveness in the post COVID 19 era, it is essential that:

I. Youths should know about their rights, and are supported to respond to social injustice, unemployment and their consequences;

II. Government and Individuals are supported to examine the nature and impact of COVID 19 and play an active role in preventing and eliminating social discrimination in job opportunities;

III. Government should create more employment opportunities for the jobs.

IV. Government should role out palliative supports for the youths;

V. Government should reopen schools and universities;

VI. Government should develop the rural communities and provide industries to reduce rural - urban drift.

VII. Youths living with any form of anger should be engaged through counseling in anyrelated area that affects them;

VIII. Institutions, such as workplaces and healthcare settings, should be supported to 
promote non-discrimination through effective workplace policies and programs;

IX. Promulgate laws and policies that do not prosecute young people and members on peaceful protest.

X. Services should be provided to enable youth who are affected to understand their rights and respond to social discrimination and its consequences.

XI. Government should monitor and respond to systemic discrimination and social injustice.

XII. Create awareness to enable communities to understand and address poverty related issues.

XIII. Create conducive environment to foster partnerships with human rights institutions, legal services and unions to promote and protect the rights of the youths and affected people.

\section{CONSENT}

As per international standard or university standard, patients' written consent has been collected and preserved by the authors.

\section{COMPETING INTERESTS}

Authors have declared that no competing interests exist.

\section{REREFENCES}

1. American Counseling Association. Code of ethics. Alexandria, VA: Author; 2005.

2. Bathje G, Pryor J. The relationship of public and self-stigma to seeking mental health services. Journal of Mental Health Counseling. 2011;33(2):161-176.

3. Studer G, Rempfer C, Waterhouse AM, Gumienny G, Haas J, Schwede T. QMEAN DisCo - distance constraints applied on model quality estimation. Bioinformatics. 2020;36:1765-1771.

4. Bertoni M, Kiefer F, Biasini M, Bordoli L, Schwede T. Modeling protein quaternary structure of homo- and hetero-oligomers beyond binary interactions by homology. Scientific Reports 7; 2017.

5. Wu F, Zhao S, Yu B, Chen YM, Wang W, Zhang $Y L$, et al. A new coronavirus associated with human respiratory disease in China. Nature. 2020;579:265-269. DOI:10.1038/s41586-020-2008-3 Medline

6. Zhou P, Yang XL, Wang XG, Hu B, Zhang $\mathrm{L}$, Zhang W, et al. A pneumonia outbreak associated with a new coronavirus of probable bat origin. Nature. 2020;579:270273.

DOI:10.1038/s41586-020-2012-7 Medline

7. Brown C, Conner KO, Copeland VC, Grote N, Beach S, Battista D, Reynolds CF. III. Depression stigma, race, and treatment seeking behavior and attitudes. Journal of Community Psychology. 2010;38:350-368.

8. Bruce N, Shapiro S, Constantino M, Manber R. Psychotherapists mindfulness and the psychotherapy process. Psychotherapy Theory, Research, Practice, Training. 2010;47(1):83-97.

9. Calicchia J, Graham L. Assessing the relationship between spirituality, life stressors, and social resources: Buffers of stress in graduate students. North American Journal of Psychology. 2006;8:307-320.

10. Corrigan P. How stigma interferes with mental health care. American Psychologist. 2004;59(7):614-625.

11. Corrigan PW, Watson AC, Barr L. The selfstigma of mental illness: Implications for self-esteem and self-efficacy. Journal of Social and Clinical Psychology. 2006;25(9):875-884.

12. Dearing $\mathrm{RL}$, Maddux JE, Tangney JP. Predictors of psychological help seeking in clinical and counseling psychology graduate students. Professional Psychology. Research and Practice. 2005;36(3):323-329.

13. Goldberstein E, Eisenberg D, Gollust S. Perceived stigma and mental health care seeking. Psychiatric Services. 2008; 59:392-399.

14. Holmes RP, Corrigan PW, Williams $\mathrm{P}$, Canar J, Kubiak MA. Changing attitudes about schizophrenia. Schizophrenia Bulletin. 1999;25:447-456.

15. Horsfall J, Cleary M, Hunt G. Stigma in mental health: Clients and professionals. Issues in Mental Health Nursing. 2010;31:450-455.

16. Hugo M. Mental health professionals attitudes towards people who have experienced a mental health disorder. Journal of Psychiatric and Mental Health Nursing. 2001;8:419-425.

17. Martin J. Stigma and student mental health in higher-education. Higher Education Research \& Development. 2010; 29(3):259-274.

18. Overton S, Medina S. The stigma of mental illness. Journal of Counseling and Development. 2008;86:143-149. 
19. Penn DL, Martin J. The stigma of severe mental illness: Some potential solutions to a recalcitrant problem. Psychiatric Quarterly. 1998;69:235-247.

20. Rogers-Sirin L. Segmented assimilation and attitudes toward psychotherapy: A moderated mediation analysis. Journal of Counseling Psychology. 2013;60(3):329339.

21. Rønnestad MH, Skovholt TM. The journey of the counselor and therapist: Research findings and perspective on professional development. Journal of Career Development. 2003;26(8):960-981.

22. Smith AL, Cashwell CS. Stigma and mental illness: Investigating attitudes of mental health and non-mental-health professionals and trainees. Journal of Humanistic Counseling, Education and Development. 2010;49:189-202.

23. Vogel DL, Bitman RL, Hammer JH, Wade NG. Is stigma internalized? The longitudinal impact of public stigma on self stigma. Journal of Counseling Psychology. 2013;60(2):311-316.

24. Vogel DL, Heimerdinger-Edwards SR, Hammer JH, Hubbard A. "Boys don't cry": Examination of the links between masculine norms and help seeking attitudes for men from diverse cultural backgrounds. Journal of Counseling Psychology. 2011;58:368-382.

25. Vogel DL, Wade NG, Ascheman P. Measuring perceptions of stigmatization by others for seeking psychological help: Reliability and validity of a new stigma scale with college students. Journal of Counseling Psychology. 2009;56:301-308.

26. Vogel DL, Wade NG, Haake S. Measuring the self-stigma associated with seeking psychological help. Journal of Counseling Psychology. 2006;51:325-327.

27. Vogel DL, Wade NG, Hackler $\mathrm{AH}$. Perceived public stigma and the willingness to seek counseling: The mediating roles of self-stigma and attitudes toward counseling. Journal of Counseling Psychology. 2007;54:40-50.

28. Vogel DL, Wester SR, Larson LM. Avoidance of counseling: Psychological factors that inhibit seeking help. Journal of Counseling \& Development. 2007;85:410422.

29. Wheeler S. What shall we do with the wounded healer? The supervisor's dilemma. Psychodynamic Practice. 2007;13(3):245-256.
30. White PE, Franzoni JB. A multidimensional analysis of the mental health of graduate counselors in training. Counselor Education and Supervision. 1990;29(4):258-268.

31. Witmer JM, Young ME. Preventing counselor impairment: A wellness approach. Journal of Humanistic Education and Development. 1996;34(3):141-155.

32. Yager GG, Tovar-Blank ZG. Wellness and counselor education. Journal of Humanistic Counseling, Education, and Development. 2007;46(2):142-153.

33. Ballesteros ML, Sanchez CM, Enjuanes L. Two amino acid changes at the $\mathrm{N}$-terminus of transmissible gastroenteritis coronavirus spike protein result in the loss of enteric tropism. Virology. 1997;227(2):378-88.

34. Baric RS, Fu K, Chen W, Yount B. High recombination and mutation rates in mouse hepatitis virus suggest that coronaviruses may be potentially important emerging viruses. Advances in Experimental Medicine and Biology. 1995;380:571-6.

35. Bonilla PJ, Gorbalenya AE, Weiss SR. Mouse hepatitis virus strain A59 RNA polymerase gene ORF 1a: Heterogeneity among MHV strains. Virology. 1994;198(2):736-40.

36. Chen N, M Zhou, X Dong, Qu J, Gong F, Han $Y$, et al. Epidemiological and clinical characteristics of 99 cases of 2019 novel coronavirus pneumonia in Wuhan, China: A descriptive study. Lancet. 2020;395:507-513.

DOI:10.1016/S0140-6736(20)30211-7 Medline

37. Huang C, Y Wang, X Li, L Ren, J Yin, H Li, et al. Clinical features of patients infected with 2019 novel coronavirus in Wuhan, China. Lancet. 2020;395:497-506.

DOI:10.1016/S0140-6736(20)30183-5

Medline

38. Tamura K, Stecher G, Peterson D, Filipski A, Kumar S. MEGA6: Molecular evolutionary genetics analysis version 6.0. Molecular Biology and Evolution. 2013;30:2725-2729.

39. Bost AG, Prentice E, Denison MR. Mouse hepatitis virus replicase protein complexes are translocated to sites of $M$ protein accumulation in the ERGIC at late times of infection. Virology. 2001;285(1):21-9.

40. Brian DA, Hogue BG, Kienzle TE. The Coronavirus hemagluttinin esterase clycoprotein. In: Siddell SG, ed. The 
Coronaviridae. New York: Plenum Press. 1995;165-79.

41. Brockway SM, Clay CT, Lu XT, Denison MR. Characterization of the expression, intracellular localization, and replication complex association of the putative mouse hepatitis virus RNAdependent RNA polymerase. Journal of Virology. 2003;77(19):10515-27.

42. Callow KA, Parry HF, Sergeant M, Tyrrell DA. The time course of the immune response to experimental coronavirus infection of man. Epidemiology and Infection. 1990;105:435-46.

43. Bost AG, Carnahan RH, Lu XT, Denison MR. Four proteins processed from the replicase gene polyprotein of mouse hepatitis virus colocalize in the cell periphery and adjacent to sites ofvirion assembly. Journal of Virology. 2000;74(7):3379-87.

44. Casais R, Thiel V, Siddell SG, Cavanagh $D$, Britton P. Reverse genetics system for the avian coronavirus infectious bronchitis virus. Journal of Virology. 2001;75(24):12359-69.

45. CDC. Update: outbreak of severe acute respiratory syndrome-Worldwide. 2020MMWR. 2020;52:241-8.

46. Anand K, Ziebuhr J, Wadhwani P, Mesters $J R$, Hilgenfeld R. Coronavirus main proteinase (3CLpro) structure: Basis for design of anti-SARS drugs. Science. 2003;300(5626):1763-7.

(c) 2020 Ubi et al.; This is an Open Access article distributed under the terms of the Creative Commons Attribution License (http://creativecommons.org/licenses/by/4.0), which permits unrestricted use, distribution, and reproduction in any medium, provided the original work is properly cited.

Peer-review history:

The peer review history for this paper can be accessed here: http://www.sdiarticle4.com/review-history/64473 